\title{
SYNTHESIS, CHARACTERIZATION AND IN VITRO BIOLOGICAL STUDIES OF NOVEL SCHIFF BASE AND ITS TRANSITION METAL COMPLEXES DERIVED FROM SULPHADOXINE
}

\author{
AMINA MUMTAZ ${ }^{1,2,3 *}$, TARIQ MAHMUD ${ }^{2}$, M.R.J. ELSEGOOD ${ }^{3}$, G.W. WEAVER ${ }^{4}$, JAVED \\ IQBAL QAZI $^{4}$, FARAH DEEBA $^{4}$ \\ ${ }^{1}$ PCSIR Laboratories complex, Ferozepur Road, Lahore, Pakistan \\ ${ }^{2}$ Institute of Chemistry, University of Punjab, Lahore 54590, Pakistan \\ ${ }^{3}$ Departemnt of Chemistry, Loughborough University, Loughborough LE11 3TU, England, UK \\ ${ }^{4}$ Department of Zoology, University of Punjab, Lahore, 54590, Pakistan
}

*corresponding author: amina.mumtaz@hotmail.com

Manuscript received: October 2017

\begin{abstract}
The new series of coordination transition metal complexes were preparedfrom Schiff base obtained from sulphadoxineandthiophene-2-carboxaldehyde. The structural investigation of Schiff base and their complexes were characterized by different instrumental procedures like microanalysis, spectroscopic andthermogravimetric examination. The integrated Schiff base ligand and transition metal complexes were subjected to antibacterial and antifungal activities. The studies demonstrated the enhanced activity of metal complexes against reported microbeswhen compared with free ligand.
\end{abstract}

\section{Rezumat}

O nouă serie de combinații complexe ale unor metale tranziționale a fost sintetizată pornind de la baza Schiff obținută din sulfadoxină și tiofen-2-carboxaldehidă. Structurile bazei Schiff şi a complecşilor au fost caracterizate prin diferite procedee instrumentale cum ar fi microanaliza, spectroscopia şi termogravimetria şi au fost investigate activitățile lor antibacteriene şi antifungice. Studiile au demonstrat o activitate antimicrobiană superioară a complexelor metalice în comparație cu ligandul liber.

Keywords: Schiff base, metal complex, sulphadoxine, thiophene-2-carboxaldehyde, Antibacterial activity.

\section{Introduction}

Recently, the significance of metal ions to the key elements of living life forms has turned out to be progressively clear. Thus, the field of bioinorganic science is currently creating at a fast pace. New models for complex natural structures and processes are being formulated and studied[1]. Many drugs have improved pharmacological properties when forming metal complexes. The Schiff base metal chelates have gained attention in fields like medicine and pharmaceutical because of wide spectrum of biological activities such as antiinflammatory drugs [2-4], antimicrobial [510], antispasmodic [11], tuberculosis [12], anticancer [13-14],antioxidants [15] and anthelmintic [16]. Aside from biological activities, Schiff bases are additionally utilizedas catalysts[17-20],dyes and pigments [21-22], polymers [23-24] and corrosion inhibitors [25-27].Schiff base assumed an impact part in the improvement of coordination science and were included as key point in the advancement of inorganic biochemistry and optical materials[28]. In the quest for novel treatment against safe life form, the alteration of existing medication by mix to a metal focus has picked up consideration as of late. Thus metal-based drug is viewed as promising options for possible substitution for current drugs. Here we report preparation, characterization and biological studies of new Schiff base transition metal complexes obtained from sulphadoxine and thiophene-2-carboxaldehyde.

\section{Materials and Methods}

Analytical grade chemicals and solvents were used in these studies. Sulphadoxine and thiophene-2carboxaldehydewere obtained from $\mathrm{BDH}$. Other pure chemicals and solvent were purchased from Alfa Aesar and used without further purification. Microanalysis was performed utilizing normal strategies. Metals in the complexes were assessed by atomic absorption spectroscopy. Basic investigations were resolved on a CE-440 Elemental analyser. FT-IR spectra were recorded with a Perkin Elmer Spectrum-100 spectrometer utilizing $\mathrm{KBr}$ pallets. NMR spectra were measured on a Jeol ECS 400 spectrometer. Mass spectra were done with the assistance of Thermo Scientific Exactive TM Plus Orbitrap spectrometer. Thermogravimetric examination for the buildings was completed on a SDT-Q600 instrument. Magnetic moments were estimated using Evans balance with anhydrous calcium chloride. Electronic absorption 
spectra of all the metal complexes were recorded on a Shimadzu-1800 spectrophotometer. The solutions of metal complexes of concentration $\left(10^{-3} \mathrm{~mol} / \mathrm{L}\right)$ were prepared and dimethyl sulphoxide (DMSO) was used as a solvent for conductance measurements using conductivity meter (4510-Jenway).

Preparation of Schiff base ligand

Sulphadoxine $(2.0 \mathrm{mmol})$ was dissolved in $2.0 \mathrm{~mL}$ of $(1 \mathrm{~N})$ sodium hydroxide. To the obtained solution an ethanolic solution of pyridoxal hydrochloride (2.0 mmol) was added and refluxed for one hour. A clear orange coloured solution was collected for isolation of Schiff base ligand by crystallization. The crystalline product was dried under vacuum and kept in a desiccator for further use.

Preparation of Schiff base metal complexes

The ligand (L) and chloride salt of copper(II), cobalt(II), zinc(II), nickel(II), manganese(II), iron(II) were dissolved in ethanol separately and after that mixed together in a $2: 1$ ratio. The reaction mixture was then refluxed for $1.0 \mathrm{~h}$. After preparation, the coloured precipitate of Schiff base metal complexes were filtered off, washed with water, ethyl alcohol and dried under reduced pressure at room temperature.

\section{Biological assay}

In vitro antimicrobial and antifungal tests were estimated by agar well diffusion method [29]. The antimicrobial activities of the synthesized compounds were investigated against Escherichia coli, Enterobacter aerogenes, Staphylococcus aureus, Bacillus pumilus, Klebsiella oxytoca and Clostridium butyrium. Mucor and Aspergillus niger were used for the antifungal studies.

\section{Results and Discussion}

The synthesis of ligand was accomplished by refluxing the sulphadoxine and thiophene-2carboxaldehyde in a molar ratio $1: 1$ in ethanol. The metal complexes of ligand were prepared using metal chloride and ligand in a 2:1 molar ratio. The structureelucidation was done with Elemental analyzer FT-IR, NMR, mass spectroscopy, TG and micro-analytical data. All the metal complexes are amorphous solids and have decomposition point. They are insoluble in water, organic solvents, partially soluble in acetone and completely soluble in DMF and DMSO. Molar conductance values (89-151 $\mu \mathrm{S} / \mathrm{cm})$ point out the electrolytic nature of metal complexes. The structures of the synthesized Schiff base ligand along with metal complexes were investigated by different techniques.

Schiff base Ligand: [N-4-(thiophene-2-ylmethyleneamino)-(5,6-dimethoxy-4-pyrimidine) benzene sulfonamide.]

Yield 75\% (Off white). M. P. $166-169^{\circ} \mathrm{C}$. IR ( $\mathrm{KBr}$, $\left.\mathrm{cm}^{-1}\right) 3241(\mathrm{NH}), 1622$ (HC=Nazomethine), 1581 $(\mathrm{C}=\mathrm{N}$-pyrimidine $), 1124(\mathrm{O}=\mathrm{S}=\mathrm{O}), 1095(\mathrm{C}-\mathrm{N})$.
Anal. Calcd. For $\mathrm{C}_{17} \mathrm{H}_{16} \mathrm{~N}_{4} \mathrm{O}_{4} \mathrm{~S}_{2}(405.06)$; Calcd: C, 50.43; H 4.20; N, 13.84; Found: C, 50.58; H 4.42; $\mathrm{N}, 13.77 \%$.

${ }^{1} \mathrm{H}$ NMR (DMSO-D $6, \delta$ ppm) $8.76(-\mathrm{CH}=\mathrm{N}), 6.51-$ 8.07 (phenyl); ${ }^{1} \mathrm{C}$ NMR (DMSO-D $6, \delta$ ppm)164.2 ($\mathrm{CH}=\mathrm{N}), 160.6$ (pyrimidine), 122.1-149.1 (phenyl). MS (EI); m/z (\%) $=405.0361\left[\mathrm{M}^{+}\right]$.

Copper (II) complex

Colour; Blue, Yield 69\%, Decomp. Point; 277$280^{\circ} \mathrm{C}$. IR; $\left(\mathrm{KBr}, \mathrm{cm}^{-1}\right) 3230(\mathrm{OH}), 1625(\mathrm{HC}=\mathrm{N}$ azomethene), $1579 \quad(\mathrm{C}=\mathrm{N}$ - pyrimidine $), \quad 1124$ $(\mathrm{O}=\mathrm{S}=\mathrm{O}), 501(\mathrm{M}-\mathrm{N}), 345$ (M-O). UV; (DMSO) $\lambda_{\max }\left(\mathrm{cm}^{-1}\right) 15345,25651$; B.M; $\left(1.97 \mu_{\mathrm{eff}}\right)$, Molar conductance $\left(121 \mu \mathrm{S} \mathrm{cm}^{-1}\right)$

Anal. Calcd. For $\mathrm{C}_{34} \mathrm{H}_{32} \mathrm{~N}_{8} \mathrm{O}_{8} \mathrm{~S}_{4} \mathrm{Cu}$ (908.50); Calcd: C, 44.90; H 3.52; N, 12.32; Cu, 6.99\%, Found: C, 45.09; H, 3.57; N, 12.38; Cu, 6.96\%.

Cobalt (II) complex

Colour; Pink, Yield; 71\%Decomp. Point; 271$274^{\circ} \mathrm{C}$, IR; $\left(\mathrm{KBr}, \mathrm{cm}^{-1}\right) 3225(\mathrm{OH}), 1624(\mathrm{HC}=\mathrm{N}$ azomethine), $1577 \quad(\mathrm{C}=\mathrm{N}-$ pyrimidine $), 1118$ $(\mathrm{O}=\mathrm{S}=\mathrm{O}), 499$ (M-N), 362 (M-O), UV;(DMSO) $\lambda_{\max }\left(\mathrm{cm}^{-1}\right) 17580,25641$; B.M; $\left(4.77 \mu_{\mathrm{eff}}\right)$, Molar conductance; $\left(92 \mu \mathrm{S} \mathrm{cm}^{-1}\right)$.

Anal.Calcd. For $\mathrm{C}_{34} \mathrm{H}_{32} \mathrm{~N}_{8} \mathrm{O}_{8} \mathrm{~S}_{4} \mathrm{Co}$ (903.89); Calcd: C,45.13; H, 3.54; N, 12.38; Co, 6.51\% Found: C,45.22; H, 3.57; N, 12.39; Co, 6.49\%.

Zinc (II) complex

Colour; Pale Yellow, Yield; 85 \%, Decomp.Point 274-279 ${ }^{\circ}$ C.IR; $\left(\mathrm{KBr}, \mathrm{cm}^{-1}\right) 3225(\mathrm{OH}), 1625(\mathrm{HC}=\mathrm{N}$ azomethine $), \quad 1578 \quad(\mathrm{C}=\mathrm{N}-$ pyrimidine $), \quad 1144$ $(\mathrm{O}=\mathrm{S}=\mathrm{O}), 493(\mathrm{M}-\mathrm{N}), 344(\mathrm{M}-\mathrm{O})$,

UV; (DMSO) $\lambda_{\max }\left(\mathrm{cm}^{-1}\right)$ 29380, Diamagnetic; Molar conductance; $\left(89 \mu \mathrm{S} \mathrm{cm}^{-1}\right)$.

Anal. Calcd. For $\mathrm{C}_{34} \mathrm{H}_{32} \mathrm{~N}_{8} \mathrm{O}_{8} \mathrm{~S}_{4} \mathrm{Zn}$ (910.34); Calcd: C, 44.81; H 3.51; N, 12.30; Zn, 7.18 \% Found: C, 44.94; H, 3.47; N, 12.31;Zn, $7.13 \%$.

Nickle (II) complex

Colour; Bluish green, Yield; 70 \%, Decomp. Point; 271-273 ${ }^{\circ} \mathrm{C}$. IR; $\left(\mathrm{KBr}, \mathrm{cm}^{-1}\right) 3226 \quad(\mathrm{OH}), 1624$ ( $\mathrm{HC}=\mathrm{N}$ azomethine), $1571 \quad(\mathrm{C}=\mathrm{N}-$ pyrimidine $)$, $1179(\mathrm{O}=\mathrm{S}=\mathrm{O}), 491(\mathrm{M}-\mathrm{N}), 324(\mathrm{M}-\mathrm{O})$,

UV; (DMSO) $\lambda \max \left(\mathrm{cm}^{-1}\right)$ 14700, 24345;B.M; $\left(3.01 \mu_{\mathrm{eff}}\right)$, Molar conductance; $\left(103 \mu \mathrm{S} \mathrm{cm}^{-1}\right)$,

Anal.Calcd.For $\mathrm{C}_{34} \mathrm{H}_{32} \mathrm{~N}_{8} \mathrm{O}_{8} \mathrm{~S}_{4} \mathrm{Ni}$ (903.65); Calcd: C, 45.15; H, 3.54; N, 12.38; Ni, 6.49\%, Found: C, 45.19; H, 3.55; N, 12.44; Ni, $6.55 \%$.

Manganese (II) complex

Color; Off-white, Yield; 71 \%Decomp. Point 266$267^{\circ} \mathrm{C}$. IR; $\left(\mathrm{KBr}, \mathrm{cm}^{-1}\right) 3237(\mathrm{OH}), 1626(\mathrm{HC}=\mathrm{N}$ azomethine $), \quad 1573 \quad(\mathrm{C}=\mathrm{N}-$ pyrimidine $), 1177$ $(\mathrm{O}=\mathrm{S}=\mathrm{O}), 501(\mathrm{M}-\mathrm{N}), 360(\mathrm{M}-\mathrm{O}), \mathrm{UV}$; (DMSO) $\lambda_{\max }\left(\mathrm{cm}^{-1}\right)$ 17880, 24630; B.M; $\left(4.59 \mu_{\mathrm{eff}}\right)$, Molar conductance; $\left(112 \mu \mathrm{S} \mathrm{cm}^{-1}\right)$

Anal. Calcd. For $\mathrm{C}_{34} \mathrm{H}_{32} \mathrm{~N}_{8} \mathrm{O}_{8} \mathrm{~S}_{4} \mathrm{Mn}$ (899.89), Anal. Calcd: C, 45.33; H, 3.55; N, 12.44; Mn, $6.10 \%$ Found: C, 45.37; H, 3.61; N, 12.49; Mn, $6.24 \%$. Iron (ll) Complexes of Ligand

Color; Peech, Yield 85\%Decomp. Point $268-272{ }^{\circ} \mathrm{C}$. IR $\quad\left(\mathrm{KBr}, \quad \mathrm{cm}^{-1}\right) 3232 \quad(\mathrm{OH}), \quad 1624 \quad(\mathrm{HC}=\mathrm{N}$ 
FARMACIA, 2019, Vol. 67, 1

azomethene), $1569 \quad(\mathrm{C}=\mathrm{N}$ - pyrimidine $), 1141$ $(\mathrm{O}=\mathrm{S}=\mathrm{O}), 489(\mathrm{M}-\mathrm{N}), 348$ (M-O). UV (DMSO) $\lambda_{\max }\left(\mathrm{cm}^{-1}\right)$ 29673, 31440; B.M $\left(5.36 \mu_{\mathrm{eff}}\right)$; molar conductance $\left(151 \mu \mathrm{S} \mathrm{cm}^{-1}\right)$.

Anal.Calcd.For $\mathrm{C}_{34} \mathrm{H}_{32} \mathrm{~N}_{8} \mathrm{O}_{8} \mathrm{~S}_{4} \mathrm{Fe}$ (900.80); Calcd: C, 45.29; H 3.55; N, 12.40; Fe, 6.19 Found: C, 45.22; H 3.51; N, 12.61; Fe, $6.13 \%$.

NMR Spectra

${ }^{1} \mathrm{H}$ NMR and ${ }^{13} \mathrm{C}$ NMR spectra were taken in $d_{6^{-}}$ DMSO. The peaks of all the proton and carbon atoms were fixed in their expected region. The NMR spectra of Schiff base ligand was confirmed the absence of aldehyde peak at $\delta \quad 9-10$ and presence of azomethine at $\delta 8.76 .{ }^{13} \mathrm{C}$ NMR spectra also verify azomethine peak at $\delta$ 164.2. The diamagnetic zinc complex showed a slight change in spectra because of increased conjugation and coordination to metal ions.

FTIR Spectra

The metal ligand bond was verified by comparing the IR spectra of the Schiff base ligands with metal (II) complexes. The FTIR spectra predicted all the absorption bands of the Schiff base ligands and some new bands at specific frequency confirmed the modes of absorption and the complexation of the ligands with the metal ions through nitrogen and oxygen.The azomethine group of ligand 1622 $\mathrm{cm}^{-1}$ was shifted to higher value $\left(1626 \mathrm{~cm}^{-1}\right)$ in all the complexes thus suggested the coordination of metal to ligand bond through azomethine $(\mathrm{HC}=\mathrm{N})$. Absorption bands of the sulfonamides moiety in the synthesized ligands and in metal complexes have same frequency.Further definitive proof of the coordination of the Schiff-bases with the metal ions was confirmed by the appearance of new bands at $489-501 \mathrm{~cm}^{-1}$ and $348-362 \mathrm{~cm}^{-1}$ designated to the metal nitrogen (M-N) and metal-oxygen (M-O) extending vibrations, respectively [30]. These bands were not present in the spectra of the free ligands, therefore affirming the presence of $\mathrm{O}$ and $\mathrm{N}$ in the coordination.

Electronic spectra and magnetic susceptibility

The electronic absorption spectra of transition metal(II) complexes were recorded in $10^{-3} \mathrm{M}$

solutions of each complex in DMSO in the range $2000-10000 \mathrm{~cm}^{-1}$ at room temperature.

The electronic absorption spectrum of the $\mathrm{Cu}(\mathrm{II})$ complex showed two bandsat $15345 \mathrm{~cm}^{-1}$ and 25651 $\mathrm{cm}^{-1}$ corresponding to the transition ${ }^{2} \mathrm{~B}_{1 \mathrm{~g}} \rightarrow{ }^{2} \mathrm{~A}_{1 \mathrm{~g}}$. No spectral bands were found below $10000 \mathrm{~cm}^{-1}$ which supported the octahedral geometry of the complex. Also, the magnetic moment value (1.97 B.M) for the $\mathrm{Cu}(\mathrm{II})$ complexes suggests the octahedral geometry with $\mathrm{dx}^{2}-\mathrm{y}^{2}$ ground state.

The electronic spectra of $\mathrm{Co}$ (II) complexes in DMSO exhibited bands around $17,580 \mathrm{~cm}^{-1}$ and a strong high-energy band at $25641 \mathrm{~cm}^{-1}$ designed ${ }^{4} \mathrm{~T}_{1 \mathrm{~g}}(\mathrm{~F}) \rightarrow{ }^{4} \mathrm{~T}_{2 \mathrm{~g}}(\mathrm{~F}),{ }^{4} \mathrm{~T}_{1 \mathrm{~g}}(\mathrm{~F}) \rightarrow{ }^{4} \mathrm{~T}_{1 \mathrm{~g}}(\mathrm{P})$ transitions respectively, for a high-spin octahedral geometry. The magnetic susceptibility measurements (4.77 B.M) for the solid $\mathrm{Co}(\mathrm{II})$ complexes are also indicative of three unpaired electrons per $\mathrm{Co}$ (II) ion consistent with their octahedral environment.

The spectrum of $\mathrm{Zn}(\mathrm{II})$ complex exhibited only one band at $29,380 \mathrm{~cm}^{-1}$ which was assigned to a ligand $\rightarrow$ metal charge transfer.The zinc (II) complexes of ligand were observed to be diamagnetic obviously and in this manner, their magnetic properties could not be calculated.

The spectrum of the Ni(II) complex showed $d-d$ bands in the region 14700 and24,345 $\mathrm{cm}^{-1}$ showed the spin-allowed transitions ${ }^{3} \mathrm{~A}_{2 \mathrm{~g}}(\mathrm{~F}) \rightarrow{ }^{3} \mathrm{~T}_{1 \mathrm{~g}}(\mathrm{~F})$ and ${ }^{3} \mathrm{~A}_{2 \mathrm{~g}}(\mathrm{~F}) \rightarrow{ }^{3} \mathrm{~T}_{1 \mathrm{~g}}(\mathrm{P})$, respectivelywith the octahedral configuration. The magnetic moment (3.01 B.M) value recommended two unpaired electrons $\mathrm{Ni}$ (II) ion also consistent with an octahedral geometry for the Ni(II) complex.

The electronic spectrum of $\mathrm{Mn}$ (II) and $\mathrm{Fe}$ (II) complexes shows ${ }^{6} \mathrm{~A}_{1 \mathrm{~g}} \rightarrow{ }^{4} \mathrm{~A}_{1 \mathrm{~g}}(\mathrm{G}),{ }^{6} \mathrm{~A}_{1 \mathrm{~g}} \rightarrow$ ${ }^{4} \mathrm{~A}_{1 \mathrm{~g}} 4 \mathrm{E}_{\mathrm{g}}$ and ${ }^{3} \mathrm{~A}_{2 \mathrm{~g}}(\mathrm{~F}) \rightarrow{ }^{3} \mathrm{~T}_{1 \mathrm{~g}}(\mathrm{P})$ and ${ }^{5} \mathrm{~T}_{2 \mathrm{~g}} \rightarrow$ ${ }^{5} \mathrm{E}_{\mathrm{g}}$ transitions respectively. The magnetic moment values of both complexes supports octahedral geometry i.e.4.59B.M and 5.36B.M[31-32].

\section{Thermal studies}

Thermogravimetric analyses (TGA) for the transition metal complexes were done from room temperature to $1000{ }^{\circ} \mathrm{C}$. Calculated and found mass losses are shown in Table below.

Table 1

Thermal Analysis Data of the Metal(II) Complexes

\begin{tabular}{|c|c|c|c|c|}
\hline S. No. & Metal Chelates & $\begin{array}{c}\text { Temperature } \\
\text { Range }\left({ }^{\circ} \mathrm{C}\right)\end{array}$ & $\begin{array}{c}\text { Mass Loss \% Found } \\
\text { (Calculated) }\end{array}$ & Assignment \\
\hline 1 & {$\left[\mathrm{Cu}(\mathrm{L}-\mathrm{H})_{2}\left(\mathrm{H}_{2} \mathrm{O}\right)_{2}\right]$} & $\begin{array}{l}120-230 \\
230-470\end{array}$ & $\begin{array}{c}4.32(3.96) \\
44.78(44.52)\end{array}$ & $\begin{array}{c}\text { Loss of } 2 \mathrm{H}_{2} \mathrm{O} \\
\text { Loss of } \mathrm{L}_{1}\end{array}$ \\
\hline 2 & {$\left[\mathrm{Co}(\mathrm{L}-\mathrm{H})_{2}\left(\mathrm{H}_{2} \mathrm{O}\right)_{2}\right]$} & $\begin{array}{l}135-235 \\
235-400\end{array}$ & $\begin{array}{c}4.18(3.98) \\
44.98(44.74)\end{array}$ & $\begin{array}{c}\text { Loss of } 2 \mathrm{H}_{2} \mathrm{O} \\
\text { Loss of } \mathrm{L}_{1}\end{array}$ \\
\hline 3 & {$\left[\mathrm{Zn}(\mathrm{L}-\mathrm{H})_{2}\left(\mathrm{H}_{2} \mathrm{O}\right)_{2}\right]$} & $\begin{array}{l}150-233 \\
233-455\end{array}$ & $\begin{array}{c}4.33(3.95) \\
45.13(44.43)\end{array}$ & $\begin{array}{c}\text { Loss of } 2 \mathrm{H}_{2} \mathrm{O} \\
\text { Loss of } \mathrm{L}_{1}\end{array}$ \\
\hline 4 & {$\left[\mathrm{Ni}(\mathrm{L}-\mathrm{H})_{2}\left(\mathrm{H}_{2} \mathrm{O}\right)_{2}\right]$} & $\begin{array}{l}118-230 \\
230-460\end{array}$ & $\begin{array}{c}4.45(3.98) \\
44.98(44.76)\end{array}$ & $\begin{array}{l}\text { Loss of } 2 \mathrm{H}_{2} \mathrm{O} \\
\text { Loss of } \mathrm{L}_{1}\end{array}$ \\
\hline 5 & {$\left[\mathrm{Mn}(\mathrm{L}-\mathrm{H})_{2}\left(\mathrm{H}_{2} \mathrm{O}\right)_{2}\right]$} & $\begin{array}{l}145-240 \\
240-475\end{array}$ & $\begin{array}{c}4.25(4.00) \\
45.25(44.94)\end{array}$ & $\begin{array}{l}\text { Loss of } 2 \mathrm{H}_{2} \mathrm{O} \\
\text { Loss of } \mathrm{L}_{1}\end{array}$ \\
\hline 6 & {$\left[\mathrm{Fe}(\mathrm{L}-\mathrm{H})_{2}\left(\mathrm{H}_{2} \mathrm{O}\right)_{2}\right]$} & $\begin{array}{l}115-227 \\
227-465 \\
\end{array}$ & $\begin{array}{c}4.32(3.99) \\
45.36(44.90) \\
\end{array}$ & $\begin{array}{c}\text { Loss of } 2 \mathrm{H}_{2} \mathrm{O} \\
\text { Loss of } \mathrm{L}_{1}\end{array}$ \\
\hline
\end{tabular}





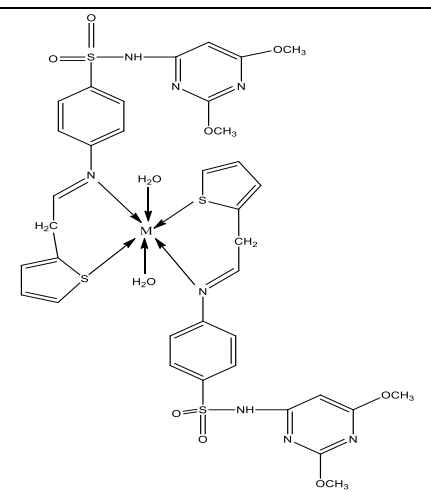

Figure 1

Proposed structure of Schiff base metal(II) complexeswhere $\mathrm{M}=\mathrm{Cu}$ (II), $\mathrm{Co}$ (II), $\mathrm{Mn}$ (II), $\mathrm{Fe}$ (II), $\mathrm{Ni}$ (II), Zn (II)
Biological activities

Antimicrobial and antifungal activity of all the synthesized transition metal complexes and Schiff base ligand were testedagainst Escherichia coli, Enterobacteraerogenes, Staphylococcus aureus, Bacillus pumilus, Klebsiellaoxytoca, Clostridium butyrium, AspergillusnigerandMucor. The results showed enhanced activity when coordinated with transition metals (Table 2). This enhancement in activity of the metal complexes as compared to free ligand can be explained by chelation therapy. The metal complexes were found to be active against Aspergillusniger and Mucor whereas parent drug and ligand showed no antifungal activity.

Table II

Antibacterial and antifungal activity of Schiff base ligand and their metal complexes (zone of inhibition; $350 \mu \mathrm{g} \mathrm{mL}-{ }^{1}$ )

\begin{tabular}{ccccccccc}
\hline Compounds & $\begin{array}{c}\text { E. coli } \\
(\mathrm{mm})\end{array}$ & $\begin{array}{c}\text { E. aerogenes } \\
(\mathrm{mm})\end{array}$ & $\begin{array}{c}\text { S. aureus } \\
(\mathrm{mm})\end{array}$ & $\begin{array}{c}\text { B. pumilus } \\
(\mathrm{mm})\end{array}$ & $\begin{array}{c}\text { K. oxytoa } \\
(\mathrm{mm})\end{array}$ & $\begin{array}{c}\text { C. butyrium } \\
(\mathrm{mm})\end{array}$ & $\begin{array}{c}\text { A. niger } \\
(\mathrm{mm})\end{array}$ & $\begin{array}{c}\text { Mucor } \\
(\mathrm{mm})\end{array}$ \\
\hline$\left[\mathrm{Cu}(\mathrm{L})_{2}\left(\mathrm{H}_{2} \mathrm{O}\right)_{2}\right]$ & $28 \pm 0.31$ & $17 \pm 0.27$ & $28 \pm 0.29$ & $17 \pm 0.15$ & $18 \pm 0.26$ & $25 \pm 0.21$ & $15 \pm 0.19$ & $17 \pm 0.18$ \\
{$\left[\mathrm{Co}(\mathrm{L})_{2}\left(\mathrm{H}_{2} \mathrm{O}\right)_{2}\right]$} & $17 \pm 0.28$ & $15 \pm 0.18$ & $20 \pm 0.21$ & $14 \pm 0.16$ & $15 \pm 0.20$ & $20 \pm 0.25$ & $11 \pm 0.22$ & $12 \pm 0.12$ \\
{$\left[\mathrm{Zn}(\mathrm{L})_{2}\left(\mathrm{H}_{2} \mathrm{O}\right)_{2}\right]$} & $24 \pm 0.23$ & $17 \pm 0.24$ & $25 \pm 0.19$ & $19 \pm 0.25$ & $19 \pm 0.11$ & $24 \pm 0.16$ & $16 \pm 0.23$ & $15 \pm 0.17$ \\
{$\left[\mathrm{Ni}(\mathrm{L})_{2}\left(\mathrm{H}_{2} \mathrm{O}\right)_{2}\right]$} & $19 \pm 0.19$ & $15 \pm 0.22$ & $19 \pm 0.09$ & $16 \pm 0.23$ & $14 \pm 0.14$ & $22 \pm 0.14$ & $13 \pm 0.29$ & $12 \pm 0.23$ \\
{$\left[\mathrm{Mn}(\mathrm{L})_{2}\left(\mathrm{H}_{2} \mathrm{O}\right)_{2}\right]$} & $16 \pm 0.25$ & $13 \pm 0.19$ & $18 \pm 0.12$ & $15 \pm 0.11$ & $15 \pm 0.18$ & $19 \pm 0.16$ & $12 \pm 0.18$ & $12 \pm 0.29$ \\
{$\left[\mathrm{Fe}(\mathrm{L})_{2}\left(\mathrm{H}_{2} \mathrm{O}\right)_{2}\right]$} & $20 \pm 0.15$ & $12 \pm 0.15$ & $17 \pm 0.18$ & $14 \pm 0.17$ & $14 \pm 0.15$ & $17 \pm 0.22$ & $12 \pm 0.22$ & $11 \pm 0.21$ \\
Ligand & $14 \pm 0.18$ & 10 & 13 & 11 & 10 & 14 & - & - \\
Drug & $11 \pm 0.21$ & $8 \pm 0.18$ & $11 \pm 0.19$ & $9 \pm 0.22$ & $9 \pm 0.21$ & $11 \pm 0.21$ & - & - \\
\hline
\end{tabular}

\section{Conclusions}

The results obtained after investigation demonstrated that derivatization of Schiff base with certain transition metal (II) ions, the antibacterial activities wereenhanced against chosen bacterial strains. The metal complexes additionally demonstrated action against Aspergillus niger and Mucor though parent drug and ligand showed no antifungal activity. These observations were in accordance with different studies, already reported that metal based drugs have more potential as therapeutics.

\section{References}

1. Sigel H, Metal ions in biological systems. $C R C$ press, 1983.

2. Sathe BS, Jaychandran E, Jagtap VA, Sreenivasa GM, Synthesis, characterization and antiinflammatory evaluation of new fluorobenzothiazole Schiff's bases. Inter J Pharm Res Dev., 2011; 3: 164169.

3. Pandey A, Dewangan D, Verma S, Mishra A, Dubey $\mathrm{RD}$, Synthesis of Schiff bases of 2-amino-5-aryl-1, 3, 4-thiadiazole and its analgesic, anti-inflammatory, antibacterial and antitubercular activity. Inter J Chem Tech Res., 2011; 3: 178-184.

4. Chandramouli C, Shivanand MR, Nayanbhai TB, Bheemachari B, Udupi RH, Synthesis and biological screening of certain new triazole Schiff bases and their derivative bearing substituted benzothiazole moiety. $J$ Chem Pharm Res., 2012; 4: 1151-1159.

5. Anacona J, Pineda Y, Bravo A, Camus J, Synthesis, characterization and antibacterial activity of a tridentate Schiff base derived from cephalexin and 1, 6-hexanediamine and its transition metal complexes. Med Chem (Los Angeles), 2016; 6: 467-473.

6. Arif M, Qurashi MMR, Shad MA, Metal-based antibacterial agents: synthesis, characterization, and in vitro biological evaluation of cefixime-derived Schiff bases and their complexes with $\mathrm{Zn}$ (II), $\mathrm{Cu}$ (II), Ni (II), and Co (II). J Coord Chem., 2011; 64: 1914-1930.

7. Naz N, Iqbal MZ, Synthesis, spectroscopic and biological studies of transition metal complexes of novel Schiff bases derived from cephradine and sugars. Sci Inter., 2011; 23: 27-31.

8. Anacona JR, Noriega N, Camus J, Synthesis, characterization and antibacterial activity of a tridentate Schiff base derived from cephalothin and sulfadiazine, and its transition metal complexes. Spectrochimica Acta Part A: Mole. Biomole. Spectro., 2015; 137, 16-22.

9. Iqbal MS, Khan AH, Loothar BA, Bukhari IH, Effect of derivatization of sulfamethoxazole and trimethoprim with copper and zinc on their medicinal value. Med Chem Resear., 2009; 18: 31-42.

10. Maurya RC, Patel P, Synthesis, magnetic and special studies of some novel metalcomplexes of $\mathrm{Cu}$ (II), Ni (II), Co (II), Zn (II), Nd (III), Th (IV), and UO2 (VI) with Schiff bases derived from sulfa drugs, viz., Sulfanilamide/Sulfamerazine and o-vanillin. Spectro lett., 1999; 32: 213-236.

11. Chaubey AK, Pandeya SN, Synthesis \& anticonvulsant activity (chem shock) of Schiff and Mannic bases of isatin derivatives with 2-amino pyridine (mechanism of action). Inter $J$ Pharm Tech Res., 2012; 4: 590-598.

12. Aboul-Fadl T, Mohammed FAH, Hassan EAS., Synthesis \& antitubercular activity and pharmacokinetic studies of some Schiff bases derived 
from 1-alkylisatin and isonicotinic acid hydrazide (INH). Arch Pharm Res., 2003; 26: 778-784.

13. Miri R, Razzaghi-as N, Mohammadi MK, QM study and conformational analysis of isatin Schiff base as a potential cytotoxic agent. J mole mod., 2013; 19: 727735.

14. Ali SMM, Azad MAK, Jesmin M, Ahsan S, Rahman M M, Khanam JA, Shahriar SMS, In vivo anticancer activity of vanillin semicarbazone. Asian Pac J Trop Biomed., 2012; 2: 438-442.

15. Wei D, Li N, Lu G, Yao K, Synthesis, catalytic and biological activity of novel dinuclear copper complex with Schiff base. Sci in China Series B Chem.,2006; 49: 225-229.

16. Avaji PG, Kumar CV, Patil SA, Shivananda KN, Nagaraju C, Synthesis, spectral characterization, invitro microbiological evaluation and cytotoxic activities of novel macrocyclicbishydrazone. Eur $J$ Med Chem., 2009; 44: 3552-3559.

17. Nishinaga A, Yamada T, Fujisawa $H$, Ishizaki $K$, Ihara $\mathrm{H}$, Matsuura $\mathrm{T}$, Catalysis of cobalt-Schiff base complexes in oxygenation of alkenes: on the mechanism ofketonization. $J$ Mole catal., 1988; 48: 249-264.

18. Xi Z, Liu W, Cao G, Du W, Huang J, Cai K, Guo H, Catalytic oxidation of naphtholby metalloporphyrins. Cuihau Xuebao, 1986; 7: 357-363.

19. Chakraborty H, Paul N, Rahman ML, Catalytic activities of Schiff base aquocomplexes of copper (II) towards hydrolysis of amino acid esters. Trans Metal Chem., 1994; 19: 524-526.

20. Belokon YN, Bulychev AG, Maleev VI, North M, Malfanov IL, Ikonnikov NS, Asymmetric synthesis of cyanohydrins catalysed by a potassium $\Delta$-bis $[\mathrm{N}-$ salicylidene-(R)-tryptophanato] cobaltate complex. Mendeleev Communi., 2004; 14: 249-250.

21. Fakhari AR, Khorrami AR, Naeimi H, Synthesis and analytical application of a novel tetradentate N2-O2 Schiff base as a chromogenic reagent for determination of nickel insome natural food samples. Talanta, 2005; 66: 813-817.
22. Befta U, Unsymmetrical 1:2 chromium complex dyes, Fabio (to Ciba Geigy AG), Eur Pat Appl EP, 1985; $148,120$.

23. George RS, Joseph RANI, George KE, Study of polySchiff's base as a protective agent in natural rubber. Inter J Polym Mater., 1993; 23: 17-26.

24. Gritskova I, Kolyachkina A, Levitin I, Paskonova E, Sigan A, Tsarkova M. Use of functionalized organocobalt initiators in processes of emulsion polymerization. Polymer Bulletin, 2006; 57: 179-188.

25. Li S, Chen S, Lei S, Ma H, Yu R, Liu D, Investigation on some Schiff bases as $\mathrm{HCl}$ corrosion inhibitors for copper. Corr Sci., 1999; 41: 1273-1287.

26. Singh AK, Quraishi MA, Study of some bidentate Schiff bases of isatin as corrosion inhibitors for mild steel in hydrochloric acid solution. Int $J$ Electrochem Sci., 2012; 7: 3222-3241.

27. Emregül KC, Atakol O, Corrosion inhibition of iron in $1 \mathrm{M} \mathrm{HCl}$ solution with Schiff base compounds and derivatives. Mater Chem \& Phys., 2004; 83: 373-379.

28. Tisato F, Refosco F, Bandoli G, Structural survey of technetium complexes. Coord Chem Rev., 1994; 135: 325-397.

29. Aulton EM, Aulton' Pharmaceutics: The design and manufacture of medicines. Churchill Livingstone Elsevier: New York, 2007.

30. Nakamoto K, Infrared of inorganic and coordination compounds. John Wiley \& Sons: New York, 1970.

31. Lever ABP, Inorganic Spectroscopy. Elsevier: Amsterdam, TheNetherlands. 1984.

32. Cotton FA, Willkinson G, Murillo CA, Bochman M, Advanced Inorganic Chemistry. John Wiley \& Sons, USA, 2003.

33. Mitra A., Basak A., Sheet D., Characterization and scanning electron microscopic investigation of crosslinked freeze dried gelatin matrices for study of drug diffusivity and release kinetics. Micron, 2012; 43(2-3): 311-320. 